\title{
Identifying and Analyzing Frequent Verbs Used in Students' Speaking and Listening Activity
}

\author{
Tita Ratna Wulandari, Cita Hikmah Yanti \\ Universitas Bina Darma, Palembang, Indonesia \\ titawulandari@binadarma.ac.id \\ citahikmahyanti@binadarma.ac.id
}

\begin{abstract}
This study discussed words used in English language. The writers aimed to know what are the most frequent words used by foreign language learners for their oral communication. The target words analysis were verbs only. Therefore, the problems of the study were formulated as follows: (1) what are most frequent verbs used in students' speaking process?,(2) what morphological process did occur?, and (3) what are the meaning of the verb found?. To answer the problems, the writers did conversation recording to a group of students. The population of this study was the English Study Program Students. The samples were taken from the 2,4 , and 6 semester students. The data were analyzed through several steps such as transcript the conversation, find the verbs, tally the verbs, make the verbs frequency, analyze the morphological process, and find the meaning of the verbs. It was found that think was the most dominantly verb occurred with 39 times out of 503 . The inflectional morphemes were usually used to modifies the verbs. It was also found that the students were still facing problems in word choice.
\end{abstract}

Keywords: Verbs, Oral Communication, and Inflectional Morphemes

\section{INTRODUCTION}

Communication is surely done by people for their daily basic needs. They communicate through verbal (spoken) or symbols (written). For instance, telling stories, giving opinions, expressing ideas, and complaining someone are what the people do with language. However, people must be able to use their communication skill properly in order to achieve their purposes in communication. Speaking and listening skills, for example, must be integratedly used whenever a person has an oral communication. If she/he fails in doing that, the conversation would not run smoothly. There might be misunderstanding or misleading information when a person cannot use the productive and receptive skills properly. As Richards, Platt, and Platt (1992) state that productive skill is the ability of producing a language and receptive skill is the ability of receiving the message of utterances.

Vocabulary mastery is one of supporting items of communication. Someone who possesses bigger vocabulary size will be able to choose and use proper vocabulary for their communication. Improper vocabulary used will influence the meaning transferred. For example, In Bahasa Indonesia, ' literally translates into English could be 'funny' or 'cute'. A speaker would be able to select which is correct for explaining "bayi anda lucu". Cute is the correct choice to explain the intended sentence. This shows that vocabulary mastery is really essential for a language user. Unfortunately, language learner faces difficulties in this vocabulary mastery and this, of course, influences communication skill.

English is the most learned language in Indonesia. It could be seen that all schools in Indonesia teach English to their students. Parents enroll their children to English courses. And, government set the policy of English as one of foreign languages which must be taught in classroom. Language learners are always trying hard to use their English in all occasion in order to be more fluent in communication.

Part of speech provides the language learners varieties of words. Traditional grammar classifies words into nine parts such as noun, pronoun, article, adjective, verb, adverb, conjunction, preposition, and interjection. Verbs express action, a state of being, and the relationship between two things. Noun is a word which names a person, place, thing, idea, animal, quality, or activity. Pronoun is a word which refers to a noun. Adjective modifies a noun or pronoun. Adverb modifies a verb, adverb, or adjective. Conjunction connects words, phrases, or clauses. Preposition precedes phrase that acts as a modifier or a noun. Interjection expresses emotion.

Those word categories are always used either in oral or written. However, the occurrence would be varied in each category. The writers believed that verbs might always occur during the communication due to their function as mentioned above. Therefore, this study aimed to see how much the occurrence of verbs in an oral communication and analyze their morphological aspects such as their morphemes. At last, the writers also explained their meaning. Finally, it is hoped that this study would be a beginning step of bigger attempt to provide the English language learners learning sources and media such as a morphology dictionary which discusses words in detail.

\section{METHODS \\ 2.1 STUDY DESIGN}

This study was done at Universitas Bina Darma, Palembang, South Sumatera. The samples were taken from the even semester students of English Study Programs, Language and Literature Faculty, academic year 2015-2016. The method of this study was multi-design study, where descriptive quantitative was used to explain the verbs occurrence and descriptive qualitative was used to explain their morphological aspects and meaning. 


\subsection{SAMPLES}

Purposive Sampling Technique was used in this study. The writers took the samples based on some criteria as follows: (1) the students have studied at least one semester as an English major student. Consequently, the students have time to explore their English skills during one semester with some subjects given. (2) the samples were not last semester students because the writers tried to avoid inconsistency of samples due to their focus. In the last semester students will focus more on their thesis. (3) the students have enrolled to speaking 1 and listening 1 class. The writers assumed that the students would be able to do oral communication better if they have taken those subjects. Seeing those criteria the second, fourth, and sixth semester students were taken as samples for this study.

\subsection{DATA COLLECTION AND ANALYSIS}

In collecting the data, the writers used these following steps: (1) group the samples, (2) assign the students to record their conversations for randomly chosen topics, (3) make the transcript, (4) select the verbs used from conversation, and (5) classify the word into their occurrence frequency using tally.

However, in analyzing the data, the writers did these steps: (1) collect the data, (2) select the verbs, (3) percentage them (4) analyze the verbs found for their morphological aspects, and (5) consult dictionary for the verbs meaning.

\subsection{MORPHOLOGY}

One of linguistics studies was morphology. As it is explained by Haspelmath (2002), Morphology is the study of the internal structure of words. One of topics discussed is morphemes. According to Yule (2010, P: 67), 'elements' in the form of a linguistics message are technically known as 'morphemes'. There are six types of morphemes discussed in this study, and they are taken from Yule (2010). Those six types of morphemes are (1) free morpheme - an independent morpheme which can stand by itself and posses a meaning such as book, door, give, and happy, (2) bound morpheme - a dependent morpheme in which it should be attached to another morpheme to posses a meaning such as $-s$, -ly, un-, and -less, (3) lexical morpheme - is also known as open class word where words are usually dynamically added. This word class includes verb, noun, adjective, and adverb such as download, sandwich, happily, and sad, (4) functional morpheme - is known as close class word where words are not dynamic. This word class includes pronoun, preposition, articles, and conjunction such as she, by, $a$, and or, (5) derivational morpheme is a bound morpheme which change the meaning and/or part of speech of a free morpheme such as happy (adj) $+-l y=$ happily (adv), and (6) inflectional morpheme is a bound morpheme which acts as a grammatical marker such as $-s$, -ing, -ed, and -er such as tall=taller, cook=cooking, and pen=pens.

\subsection{ORAL COMMUNICATION SKILL}

Doing oral communication means the language users use two skills of language integratedly, namely speaking and listening. Fromkin and Rodman (1998) state that this two skills help language users go through understanding process of utterances, and this also helps them relates brain of the speakers to the brain of the listeners. Literally, speaking skill could be defined as an activity of producing sounds with certain patterns so it transfer meaning to listeners. Meanwhile, listening skill is defined as an activity of receiving sounds and getting meaning from them.

\section{FINDINGS \\ 3.1 VERBS OCCURRENCE}

It is found that there were five hundred and three verbs (503) occur during the recording. The highest occurrence was 'think' with thirty nine (39) times uttered (7.8\%), 'know' with thirty three (33) times uttered (6.6\%), 'like' with twenty nine (29) times uttered (5.8\%), 'go' with twenty one (21) times uttered (4.2\%), "have' with twenty (20) times uttered (4\%), 'see' with sixteen (16) times uttered (3.2\%), 'do' with fifteen (15) times uttered (3\%), 'want' with twelve (12) times uttered (2.4\%), 'come on', 'look', 'watch' with ten (10) times uttered (2\%), 'love' and 'make' with nine (9) times uttered (1.8\%), 'call' with eight (8) times uttered (1.6\%), 'going' with seven (7) times uttered (1.4\%), 'give' with six (6) times uttered (1.2\%), 'got', 'join', 'talk', 'tell' with five (5) times uttered (1\%), 'change', 'come', 'get', 'hate', 'hear', 'invite', 'meet', 'say', 'sing', 'start', 'stay', 'try', 'wait' with four (4) times uttered (0.8\%), 'ask', 'done', 'drink', 'eat', 'fit', 'hope', 'live', 'mean', 'play', 'saw', 'take', 'text', 'tried', 'wear' with three (3) times uttered (0.4\%), 'agree', 'became', 'being', 'believe', 'broke up', 'brought', 'care', 'check', 'coming', 'decrease', 'enjoy', 'feel', 'finish', 'get out', 'hang out', 'happen', 'improve', 'increase', 'learn', 'made', 'need', 'read', 'release', 'scream', 'shoot', 'solve', 'study', 'swing', 'told', 'use' with two (2) times uttered (0.4\%), 'arrived', 'avoid', 'born', 'borrow', 'building', 'built', 'cheat', 'choose', 'compare', 'contact', 'dance', 'decide', 'doing', 'download', 'dribble', 'drive', 'driving', 'earn', 'fell', 'fixed', 'follow', 'following', 'forgot', 'gathering', 'guess', 'had', 'handle', 'has', 'heard', 'hurt', 'ignores', 'left', 'lie', 'listening', 'melt', 'mention', 'message', 'mind', 'order', 'pass', 'permit', 'practice', 'pray', 'prefer', 'refresh', 'register', 'reply', 'ride', 'run', 'said', 'save', 'send', 'sent', 'share', 'show', 'sleep', 'slow down', 'smile', 'stress', 'supposed', 'take care', 'taken', 'talking', 'taste', 'teach', 'traveling', 'treat', 'turn on', 'went', 'wish', 'work', 'yelling' only once occurred $(0.2 \%)$.

\subsection{MORPHEMES ANALYSIS}

Inflectional morphemes were majorly occurred to those verbs found such as going, tried, being, coming, arrived, building, doing, driving, fixed, following, gathering, ignores, listening, supposed, talking, traveling, and yelling. The morphemes are only grammatical marker as it was shown on this Table 1 
Table 1: Inflectional Morphemes Process

\begin{tabular}{cll}
\hline No & \multicolumn{1}{c}{ Words } & \multicolumn{1}{c}{ Inflectional Morphemes } \\
\hline 1 & going & Go + -ing (present participle marker) \\
\hline 2 & tried & Try + -ed (past participle marker) \\
\hline 3 & Being & Be + -ing (present participle marker) \\
\hline 4 & Coming & Come + -ing (present participle marker) \\
\hline 5 & Arrived & Arrive + -ed (past participle marker) \\
\hline 6 & Building & Build + -ing (present participle marker) \\
\hline 7 & Doing & Do + -ing (present participle marker) \\
\hline 8 & Driving & Drive + -ing (present participle marker) \\
\hline 9 & Fixed & Fix + -ed (past participle marker) \\
\hline 10 & Following & Follow + -ing (present participle marker) \\
\hline 11 & Gathering & Gather + -ing (present participle marker) \\
\hline 12 & Ignores & Ignore + -s (third persent singular marker) \\
\hline 13 & Listening & Listen + -ing (present participle marker) \\
\hline 14 & Supposed & Suppose + -ed (past participle marker) \\
\hline 15 & Talking & Talk + -ing (present participle marker) \\
\hline 16 & Traveling & Travel + -ing (present participle marker) \\
\hline 17 & Yelling & Yell + -ing (present participle marker) \\
\hline
\end{tabular}

\subsection{MEANING}

In meaning analysis, the writers tried to translate the verbs found into Bahasa Indonesia. 'think' means pikir or rasa, 'know' means tahu, 'like' means suka, 'go' means pergi, 'have' means memiliki, 'see' means melihat or mengerti, 'do' means melakukan or melaksanakan, 'want' means ingin, 'come on' means ayolah, 'look' means melihat, 'watch' means menonton, 'love' means mencintai, 'make' means membuat, 'call' means menelpon, 'going' means pergi, 'give' means memberikan, 'got' means mendapatkan, 'join' means mengikuti, 'talk' means berbicara, 'tell' means memberitahu, 'change' means mengubah, 'come' means datang, 'get' means mendapatkan, 'hate' means membenci, 'hear' means mendengarkan, 'invite' means mengundang, 'meet' means bertemu, 'say' means mengatakan, 'sing' means bernyanyi, 'start' means memulai, 'stay' means menempati, 'try' means mencoba, 'wait' means menunggu, 'ask' means meminta, 'done' means melaksanakan, 'drink' means meminum, 'eat' means memakan, 'fit' means cocok, 'hope' means mengharap, 'live' means tinggal, 'mean' means berarti, 'play' means bermain, 'saw' means melihat, 'take' means mengambil, 'text' means mengirimkan pesan, 'tried' means mencoba, 'wear' means memakai, 'agree' means menyetujui, 'became' means menjadi, 'being' means menjadi, 'believe' means mempercayai, 'broke up' means putus hubungan, 'brought' means membawa, 'care' means perduli, 'check' means memeriksa, 'coming' means datang, 'decrease' means mengurangi, 'enjoy' means menikmati, 'feel' means merasakan, 'finish' means selesai, 'get out' means keluar, 'hang out' means jalan-jalan, 'happen' means terjadi, 'improve' means meningkatkan, 'increase' means meningkatkan, 'learn' means belajar, 'made' means membuat, 'need' means membutuhkan, 'read' means membaca, 'release' means melepaskan, 'scream' means berteriak, 'shoot' means menembak, 'solve' means menyelesaikan, 'study' means belajar, 'swing' means berubah, 'told' means berbicara, 'use' means menggunakan, 'arrived' means tiba, 'avoid' means menghindari, 'born' means lahir, 'borrow' means meminjamkan, 'building' means membangun, 'built' means membangun, 'cheat' means mencontek, 'choose' means memilih, 'compare' means membandingkan, 'contact' means menghubungi, 'dance' means berdansa, 'decide' means memutuskan, 'doing' means melakukan, 'download' means mengunduh, 'dribble' means menggiring bola, 'drive' means mengemudi, 'driving' means mengemudi, 'earn' means menghasilkan, 'fell' means merasakan, 'fixed' means memperbaiki, 'follow' means mengikuti, 'following' means mengikuti, 'forgot' means melupakan, 'gathering' means berkumpul, 'guess' means menebak, 'had' means memiliki, 'handle' means mengatasi, 'has' means memiliki, 'heard' means mendengar, 'hurt' means menyakiti, 'ignores' means mengacuhkan, 'left'means meninggalkan, 'lie' means berbohong, 'listening' means mendengarkan, 'melt' means mencair, 'mention' means menyebutkan, 'message' means mengirimkan pesan, 'mind' means berkeberatan, 'order' means memesan, 'pass' means lulus, 'permit' means mengijinkan, 'practice' means berlatih, 'pray' means berdoa, 'prefer' means menyukai, 'refresh' means menyegarkan, 'register'means mendaftarkan, 'reply' means menjawab, 'ride' means mengendarai, 'run' means berlari, 'said' means berkata, 'save' means menyimpan, 'send' means mengirimkan, 'sent' means mengirimkan, 'share' means berbagi, 'show' means pertunjukkan, 'sleep' means tidur, 'slow down' means memperlambat, 'smile' means tersenyum, 'stress' means menekankan, 'supposed' means bertujuan, 'take care' means perhatian, 'taken' means mengambil, 'talking' means berbicara, 'taste' means merasakan, 'teach' means mengajari, 'traveling' means berpergian, 'treat' means memperlakukan, 'turn on' means menyalakan, 'went' means pergi, 'wish' means mengharapkan, 'work' means berkerja, 'yelling' means berteriak.

\section{RESULT DISCUSSION}

The most dominant verb used was 'think'. This was used as an expression of giving ideas or opinion about something based on the speaker thought. Speaker dominantly used this in order to show the signal of what is uttered in the next sentence is purely his or her opinion. Meanwhile, other words occurred in very varied condition. They occurred because the speakers need to explain something properly. Furthermore, the speaker, indirectly, are able to use morphemes in variation since it had been found that there were some inflectional morphemes occurred such third person marker, past tense marker, and present participle marker. Moreover, it is accepted why are only inflectional morphemes found because this study only focused on verb. However, students still needed to improve their ability in word choices where the writers still found wrong vocabulary used. For example, a student said because lots of people brought a car, what should be highlighted is the word 'brought'. The speaker misused the word 'brought' where it should be changed by 'drive'. It is fully understood that this was happened due to students' L1 influences. In their L1, membawa could be used to describe mengendarai. Meanwhile, English has different meaning. 


\section{CONCLUSION}

From the study above, it could be concluded that inflectional morphemes dominantly occurred in verbs. In addition, the language learners must try hard to improve their knowledge of word choice in order to be able to use proper word to explain something.

\section{REFERENCES}

Fromkin, V. \& Rodman, R. (1998). An Introduction to Language- 6th ed.). Fort Worth: Harcourt Brace College Publishers.

Haspelmath, M. (2002). Understanding Morphology. London: Arnold.

Richards, J. C., Platt, J. \& Platt, H. (1992).Longman dictionary of language teaching and applied linguistics.Edinburgh, UK: Longman.

Yule, G. (2010). The Study of Language. 4th Edition. Cambridge, UK: Cambridge University Press. 